\title{
Low back pain in Hong Kong: prevalence and characteristics compared with Britain
}

\author{
E M C Lau, P Egger, D Coggon, C Cooper, L Valenti, D O'Connell
}

\begin{abstract}
Study objective - To compare the prevalence of low back pain and associated disability in Hong Kong with that in Britain, and to explore whether differences could be explained by certain known risk factors.

Design - A cross sectional survey with information collected at interview. Findings were compared with those from an earlier survey in Britain.

Setting - Two housing blocks in Hong Kong.
\end{abstract}

Subjects - Altogether 288 men and 364 women aged 18 years or older, who were resident in the two housing blocks and agreed to interview (response rate $=80 \%$ ). Main results - Thirty nine per cent $(95 \%$ confidence interval (CI) $34 \%, 44 \%$ ) of interviewees reported having had low back pain at some time, and $21 \%(95 \%$ CI $18 \%$, $25 \%)$ had had low back pain in the past 12 months. After standardisation for age and sex, all of the back symptoms examined were substantially less common in Hong Kong than in Britain. The one year period prevalence of low back pain was associated with occupational lifting (in both sexes) and with tall stature (in men only). Subjects tended to carry out less heavy lifting at work and to be shorter than participants in the earlier British study but these differences did not completely explain their lower prevalence of back pain.

Conclusions - The findings indicate a lower prevalence of back symptoms in Hong Kong than Britain that is partly explained by differences in stature and occupational lifting. In addition, Hong Kong people may have a higher threshold for reporting symptoms, or they may differ in their exposure to other, unrecognised risk factors.

\section{( $\mathcal{F}$ Epidemiol Community Health 1995;49:492-494)}

Low back pain is a common complaint and major cause of disability in western countries. Cross sectional surveys of the general population in Britain, ${ }^{1}$ Denmark, ${ }^{2}$ Finland, ${ }^{3}$ The Netherlands, ${ }^{4}$ and Sweden ${ }^{5}$ have recorded lifetime prevalences in the range $50-80 \%$; and one year period prevalences of $25 \%{ }^{6}$ and $36 \%{ }^{1}$ have been reported in Denmark and Britain. Little is known, however, about the occurrence of low back symptoms in other parts of the world. It is important to establish this because geographical differences in prevalence might provide useful clues to aetiology. We report a survey of low back pain and associated disability among the Chinese population of Hong Kong, in whom symptoms were ascertained by questions translated from those used in an earlier British study. ${ }^{17}$ This allowed a direct comparison between the two countries.

\section{Methods}

The study population comprised adult residents of two housing blocks in Shatin, a new town in Hong Kong. One block was made up of government subsidised housing reserved for households with a monthly income of HK $\$ 9000$ or less. The second block was privately owned and occupied by more affluent people.

Each household in the two blocks was sent a letter of invitation informing them of the survey and giving dates for a proposed visit by an interviewer. At the visit, a list was made of all members of the household aged 18 years or older, and each person was asked to answer a questionnaire. Those who were not at home at the time of the first contact were revisited later. An apartment was considered unoccupied only if no one was there at any of three separate visits.

The questionnaire was based on that used in a previous survey of back pain in Britain, ${ }^{17}$ and included a direct translation of the questions concerning symptoms and disability. Subjects were asked whether they had ever had back pain lasting for more than a day in an area (illustrated with a diagram) between the lower costal margins and the gluteal folds, and whether they had had such pain within the past 12 months. Those who reported pain were asked whether the pain had ever spread down the leg to below the knee (sciatica); whether it was of sudden or gradual onset; how long it had lasted in total; and whether the pain had made it difficult or impossible to walk, stand for 15 minutes, get up from a low chair, get out of a bath, get in and out of a car, put on shoes, socks, stockings, or tights, go up and down stairs, or cut toenails. Disabilities in relation to these eight activities were scored (one if the activity was made difficult and two if impossible) and the scores were summed to derive an overall disability score. In addition, subjects were asked to report their height and to give a lifetime occupational history, indicating whether or not their jobs had entailed heavy lifting. The latter was defined as lifting or moving weights of more than $25 \mathrm{~kg}$ by hand in an average working day.

The prevalence of low back pain and associated disability was examined in relation to age, sex, housing status, height, and exposure 
Table 1 Prevalence \% (no) cases of low back pain in relation to age and sex in Hong Kong men and women

\begin{tabular}{llllll}
\hline & \multicolumn{2}{l}{ Low back pain ever } & & \multicolumn{2}{l}{ Low back pain in past 12 mth } \\
\cline { 2 - 3 } Age & Men & Women & & Men & Women \\
\hline$<20$ & $36(8)$ & $22(10)$ & $14(3)$ & $11(5)$ \\
$20-29$ & $36(33)$ & $36(39)$ & $24(22)$ & $20(22)$ \\
$30-39$ & $28(18)$ & $44(33)$ & & $14(9)$ & $21(15)$ \\
$40-49$ & $39(7)$ & $59(13)$ & & $22(4)$ & $41(9)$ \\
$50-59$ & $47(14)$ & $56(24)$ & & $14(4)$ & $33(14)$ \\
$60-69$ & $43(20)$ & $42(21)$ & & $17(8)$ & $28(14)$ \\
$70+$ & $31(4)$ & $67(12)$ & $25(3)$ & $39(7)$ \\
\hline
\end{tabular}

Table 2 Standardised prevalence (\%) of back symptoms in Hong Kong and British men and women aged $20-59$

\begin{tabular}{|c|c|c|}
\hline Symptom & $\begin{array}{l}\text { Hong Kong } \\
\text { prevalence }(95 \% \text { CI) }\end{array}$ & $\begin{array}{l}\text { Britain } \\
\text { prevalence }(95 \% \mathrm{CI})\end{array}$ \\
\hline $\begin{array}{l}\text { Low back pain - ever } \\
\text { Sciatica - ever } \\
\text { Low back pain of sudden onset - ever } \\
\text { Low back pain making it impossible to put } \\
\text { on socks, stockings or tights - ever } \\
\text { Low back pain associated with a disability } \\
\text { score } \geq 9 \text { - ever } \\
\text { Low back pain lasting more than } 4 \text { wk in } \\
\text { total - ever } \\
\text { Low back pain - past } 12 \text { mth } \\
\text { Low back pain making it impossible to put } \\
\text { on socks, stockings or tights - past } 12 \mathrm{mth} \\
\text { Low back pain associated with a disability } \\
\text { score } \geq 9 \text { - last } 12 \text { mth }\end{array}$ & $\begin{array}{c}39 \cdot 7(34 \cdot 1,45 \cdot 9) \\
9 \cdot 1(6 \cdot 5,12 \cdot 4) \\
17 \cdot 0(13 \cdot 5,21 \cdot 3)\end{array}$ & $\begin{array}{l}55 \cdot 1(48 \cdot 2,61 \cdot 9) \\
19 \cdot 6(15 \cdot 7,24 \cdot 1) \\
42 \cdot 8(36 \cdot 9,49 \cdot 2)\end{array}$ \\
\hline
\end{tabular}

Prevalences are directly standardised for age (in 10-year strata) and sex with the age and sex distribution of the Hong Kong study sample as standard.

to heavy lifting at work. It was compared with that in the earlier British survey with rates directly standardised for age (in 10 year strata) and sex, using the age and sex distribution of the Hong Kong sample as the standard. To assess whether differences in the occurrence of back pain between Hong Kong and Britain could be explained by differences in measured risk factors, we carried out a logistic regression analysis with low back pain in the past 12 months as the outcome variable and including country of residence as one of the independent variables.

\section{Results}

Interviews were completed by 288 men and 364 women, giving an overall response rate of $80 \%$. One hundred and forty two of the responders lived in private housing (response rate $=78 \%$ ) and 510 in subsidised housing (response rate $=81 \%$ ).

Altogether $39 \%(95 \%$ CI $34 \%, 44 \%)$ of interviewees reported having had low back pain at some time and $21 \%(95 \%$ CI $18 \%, 25 \%)$ had had the symptom during the past 12 months. Table 1 shows the lifetime and 12 month period prevalence of low back pain according to age and sex. Pain in the past 12 months was reported least often by people below age 20 but otherwise there were no clear patterns in relation to age. In general, women reported symptoms more frequently than men of the same age.

Table 2 compares the prevalence of symptoms in subjects aged 20-59 with that found previously in British people of the same age. After standardisation for age and sex, all of the symptoms examined were substantially less common in Hong Kong. Almost all occurred at less than half the rate in Britain.

Table 3 shows the one year period prevalence of low back pain in Hong Kong and British men and women aged 20-59 according to their height. In both countries, taller men tended to report back pain more frequently than their shorter compatriots, whereas there was no consistent relation between back pain and stature in women. British people were taller on average than those from Hong Kong, but within all but one stratum of height the prevalence of back pain was higher in Britain than in Hong Kong.

In both Hong Kong and Britain, back pain during the past 12 months was most common in men and women with jobs that entailed regularly lifting weights in excess of $25 \mathrm{~kg}$ (table 4). When account was taken of such lifting, however, rates of back pain remained higher in Britain.

In a logistic regression model with back pain in the past 12 months as the outcome, the higher risk in Britain than Hong Kong remained significant after adjustment for age (in 10 year strata), sex, height (stratified as in table 3), occupational lifting (classified as in table 4), and the interaction of sex and height (adjusted odds ratio, $1 \cdot 3,95 \%$ CI $1 \cdot 0,1 \cdot 7)$.

\section{Discussion}

Our findings indicate that low back symptoms are common in Hong Kong Chinese, but that their prevalence is substantially lower than in Britain. The Hong Kong and British studies used identical questions to ascertain back pain but differed in that the former elicited histories at interview, whereas the latter was based on a self administered postal questionnaire. If anything, we would expect ascertainment of symp-

Table 3 Age standardised prevalence (\%) of low back pain during the past 12 months according to height in Hong Kong and British men and women aged 20-59 years

\begin{tabular}{|c|c|c|c|c|c|c|}
\hline \multirow[b]{2}{*}{ Height (cm) } & \multicolumn{3}{|c|}{ Hong Kong } & \multicolumn{3}{|l|}{ Britain } \\
\hline & $\begin{array}{l}\text { No of } \\
\text { subjects }\end{array}$ & $\begin{array}{l}\text { No of } \\
\text { cases }\end{array}$ & $\begin{array}{l}\text { Prevalence } \\
(95 \% \mathrm{CI})\end{array}$ & $\begin{array}{l}\text { No of } \\
\text { subjects }\end{array}$ & $\begin{array}{l}\text { No of } \\
\text { cases }\end{array}$ & $\begin{array}{l}\text { Prevalence } \\
(95 \% \mathrm{CI})\end{array}$ \\
\hline $\begin{array}{l}\text { Men: } \\
\quad \leq 165 \\
166-168 \\
169-170 \\
171-175 \\
\geq 176\end{array}$ & $\begin{array}{l}58 \\
34 \\
45 \\
36 \\
25\end{array}$ & $\begin{array}{r}7 \\
6 \\
11 \\
9 \\
5\end{array}$ & $\begin{array}{l}12(5,25) \\
18(6,38) \\
24(12,44) \\
25(11,47) \\
20(6,47)\end{array}$ & $\begin{array}{r}72 \\
74 \\
106 \\
281 \\
593\end{array}$ & $\begin{array}{r}18 \\
19 \\
33 \\
109 \\
243\end{array}$ & $\begin{array}{l}27(17,43) \\
19(10,32) \\
33(23,46) \\
36(30,44) \\
40(35,45)\end{array}$ \\
\hline $\begin{array}{l}\text { Women: } \\
\leq 152 \\
153-155 \\
156-159 \\
160-162 \\
\geq 163\end{array}$ & $\begin{array}{l}58 \\
43 \\
51 \\
45 \\
26\end{array}$ & $\begin{array}{r}14 \\
11 \\
10 \\
12 \\
8\end{array}$ & $\begin{array}{l}24(13,40) \\
26(13,46) \\
20(9,36) \\
27(14,47) \\
31(13,61)\end{array}$ & $\begin{array}{r}120 \\
97 \\
252 \\
203 \\
731\end{array}$ & $\begin{array}{r}43 \\
34 \\
91 \\
54 \\
266\end{array}$ & $\begin{array}{l}34(25,46) \\
30(20,43) \\
32(26,40) \\
19(14,26) \\
32(28,36)\end{array}$ \\
\hline
\end{tabular}


Table 4 Age standardised prevalence (\%) of low back pain during the past 12 months according to history of occupational lifting in Hong Kong and British men and women aged 20-59 years

\begin{tabular}{|c|c|c|c|c|c|c|}
\hline \multirow[b]{2}{*}{$\begin{array}{l}\text { Heavy lifting } \\
\text { at work }\end{array}$} & \multicolumn{3}{|c|}{ Hong Kong } & \multicolumn{3}{|l|}{ Britain } \\
\hline & $\begin{array}{l}\text { No of } \\
\text { subjects }\end{array}$ & $\begin{array}{l}\text { No of } \\
\text { cases }\end{array}$ & $\begin{array}{l}\text { Prevalence } \\
(95 \% \text { CI) }\end{array}$ & $\begin{array}{l}\text { No of } \\
\text { subjects }\end{array}$ & $\begin{array}{l}\text { No of } \\
\text { cases }\end{array}$ & $\begin{array}{l}\text { Prevalence } \\
(95 \% \text { CI) }\end{array}$ \\
\hline \multirow{2}{*}{$\begin{array}{l}\text { Men: } \\
\text { Never } \\
\text { In past but not in } \\
\text { current job } \\
\text { In current job }\end{array}$} & 130 & 24 & $18(12,27)$ & 375 & 100 & $23(19,29)$ \\
\hline & $\begin{array}{l}34 \\
34\end{array}$ & $\begin{array}{l}6 \\
8\end{array}$ & $\begin{array}{l}18(6,38) \\
24(10,46)\end{array}$ & $\begin{array}{l}271 \\
476\end{array}$ & $\begin{array}{r}95 \\
227\end{array}$ & $\begin{array}{l}34(28,42) \\
48(42,55)\end{array}$ \\
\hline \multirow{2}{*}{$\begin{array}{l}\text { Women: } \\
\text { Never } \\
\text { In past but not in } \\
\text { current job } \\
\text { In current job }\end{array}$} & 188 & 44 & $23(17,31)$ & 1132 & 358 & $28(25,31)$ \\
\hline & $\begin{array}{l}23 \\
12\end{array}$ & $\begin{array}{l}7 \\
4\end{array}$ & $\begin{array}{l}30(12,63) \\
33(9,85)\end{array}$ & $\begin{array}{l}143 \\
128\end{array}$ & $\begin{array}{l}58 \\
72\end{array}$ & $\begin{array}{l}40(31,52) \\
54(42,68)\end{array}$ \\
\hline
\end{tabular}

toms by interview to be more complete and this difference is, therefore, unlikely to explain the higher frequency of low back pain recorded in Britain.

Another difference between the surveys was the method by which subjects were recruited. The British sample was selected from the agesex registers of general practices but in Hong Kong there are no suitable population registers which can be used as a sampling frame. Again, however, the variation in method is unlikely to explain the different prevalence of symptoms in the two countries. Even among the Chinese people living in subsidised housing, the rate of symptoms, although higher than in more affluent Chinese, was appreciably lower than in the British survey.

Two of the best established risk factors for low back disorders are tall stature and heavy lifting. The association with stature has been frequently shown in studies of men, ${ }^{6-14}$ although it has not been a consistent finding in women. $^{79-1114-16}$ Our results conform to this pattern and it is notable that the relation to stature was apparent in the height range of Hong Kong men, which is rather lower than that of men in Europe and North America. The shorter stature of the Hong Kong men did not, however, explain fully their lower prevalence of back pain as compared with Britain

As in many other studies, ${ }^{578-17}$ back pain in Hong Kong was associated with heavy lifting at work, both in men and women. Such lifting was less common in Hong Kong than in Britain but again the difference did not seem to explain completely the lower prevalence of back disorders in Hong Kong. Even among people whose work had never required them regularly to lift or move weights in excess of $25 \mathrm{~kg}$, rates of back pain were higher in Britain than in Hong Kong.

Another factor which may have contributed to the lower prevalence of back complaints in Hong Kong is differences in people's threshold for reporting symtpoms. Back pain is known to be reported more frequently by people with depression and by those who complain of other common symptoms such as headache and dysmenorrhoea, ${ }^{16-18}$ possibly because these people are more aware of painful stimuli. Perhaps the Hong Kong Chinese are less conscious of back pain than their British counterparts. This hypothesis is difficult to evaluate because the pathogenesis of low back disorders is poorly understood and in most sufferers there are no reliable objective markers of disease. However, in western countries a substantial minority of cases result from prolapsed intervertebral discs, which can be diagnosed objectively, for example by magnetic resonance imaging. A survey comparing the occurrence of prolapsed disc in Britain and Hong Kong might help to clarify the contribution of reporting bias.

In summary, differences in stature and occupational lifting do not seem to explain completely the lower prevalence of back pain in Hong Kong compared with Britain. It would be helpful to establish the frequency of back disorders in other non-European populations, and particularly of prolapsed intervertebral discs.

1 Walsh K, Cruddas M, Coggon D. Low back pain in eight areas of Britain. 7 Epidemiol Community Health 1992;46: 227-30.

2 Biering-Sorensen F. Low back trouble in a general population of 30-, 40-, 50-, and 60-year old men and women. Study design, representativeness and basic results. Dan Med Bull 1982;29:289-99.

3 Heliövaara M. Epidemiology of sciatica and herniated lumbar intervertebral disc. Helsinki: Publications of the Social Insurance Institution, Finland, ML76, 1988.

4 Valkenburg HA, Haanen HCM. The epidemiology of low back pain. In: White AA, Gordon SL, eds. Idiopathic low back pain. St. Louis: CV Mosby, 1982.

5 Svensson HO, Andersson GBJ. Low-back pain in 40-47year-old men: work history and work environment factors. Spine 1983;8:272-6.

6 Gyntelberg F. One year incidence of low-back pain among male residents of Copenhagen aged 40-59. Dan Med Bull 1974;21:30-6.

7 Walsh K, Cruddas M, Coggon D. Interaction of height and mechanical loading of the spine in the development of low-back pain. Scand $\mathcal{f}$ Work Environ Health 1991;17 420-4.

8 Lawrence JS. Rheumatism in coal miners. III. Occupationa factors. $\mathrm{Br} \mathcal{F}$ Ind Med 1955;12:249-61.

9 Biering-Sorensen F. Physical measurements as risk indicators for low-back trouble over a one-year period. Spine 1984;9:106-19.

10 Heliövaara $M$. Body height, obesity and risk of herniated lumbar intervertebral disc. Spine 1987;12:469-72.

11 Kelsey JL. An epidemiological study of acute herniated lumbar intervertebral discs. Rheumatology and Relumbar intervertebral discs.

12 Undeutsch K, Gartner KH, Luopajarvi T et al. Back complaints and findings in transport workers performing physically heavy work. Scand $\mathcal{f}$ Work Envinon Health 1982; 8(suppl 1): $92-6$

13 Hrubec Z, Nashold BS. Epidemiology of lumbar disc lesions in the military in World War II. Am f Epidemiol 1975;102: 366-76.

14 Kuh DJL, Coggon D, Mann S, Cooper C, Yusuf E. Height, occupation and back pain in a national prospective study. Br f Rheumatol 1993;32:911-6.

15 Hirsch C, Jonsson B, Lewin T. Low-back symptoms in a Swedish female population. Clin Orthop 1969;63:171-6.

16 Smedley J, Egger P, Cooper C, Coggon D. Manual handling activities and risk of back pain in nurses. Occup Environ Med (in press.)

17 Frymoyer JW, Pope MH, Costanza MC, Rosen JC, Goggin JE, Wilder DG. Epidemiologic studies of low back pain Spine 1980;5:419-23.

18 Nagi SZ, Riley LE, Newby LG. A social epidemiology of back pain in a general population. $\mathcal{F}$ Chron Dis 1973;26: 769-79.

19 Croft P, Ferry S, Papageorgiou A, Jayson M, Silman A. Depression and back pain in the general population. Proceedings of the British Society of Rheumatology 1994. 